\title{
Editorial
}

\section{REVITALISASI MANAJER PELAYANAN PASIEN}

\author{
NICO LUMENTA' DAN HANEVI DJASRI ${ }^{2}$ \\ ${ }^{1}$ Komisi Akreditasi Rumah Sakit (KARS) \\ ${ }^{2}$ Pusat Kebijakan dan Manajemen Kesehatan (PKMK), Fakultas Kedokteran, Kesehatan Masyarakat dan \\ Keperawatan, Universitas Gadjah Mada (FK-KMK UGM)
}

Email korespondensi: nico@kars.or.id

Pandemi Covid-19 menunjukkan pentingnya pendekatan interdisipliner dalam tatalaksana pasien, tidak saja lintas profesi dan cabang keilmuan, namun juga lintas unit dan fasilitas pelayanan kesehatan ${ }^{1,2}$. Dengan semakin kompleksnya pelayanan kesehatan yang dibutuhkan, maka peran case manager menjadi sangat penting. Di Indonesia, case manager atau Manajer Pelayanan Pasien (MPP) telah diperkenalkan di rumah sakit (RS) sejak 10 tahun lalu melalui standar akreditasi. Diawali dengan Standar Akreditasi Rumah Sakit dalam bab Standar Akses ke Pelayanan dan Kontinuitas Pelayanan (APK), yang kemudian dilanjutkan dalam Standar Nasional Akreditasi Rumah Sakit (SNARS) pada bab Akses ke Rumah Sakit dan Kontinuitas Pelayanan (ARK) 3,4 . Berbagai penelitian menunjukkan bahwa MPP yang efektif dapat mengurangi jumlah kunjungan pasien, penggunaan tes diagnostik, lama rawat inap, dan biaya di institusi ${ }^{5}$. Meskipun keberadaan MPP telah dikenal dan mulai dilaksanakan di berbagai RS, akan tetapi masih sering kali terbatas pada pemenuhan standar akreditasi. Oleh karenanya, peran MPP perlu dipertegas dan diperkuat melalui upaya revitalisasi.

Revitalisasi MPP dilakukan dengan kembali mempelajari dan menerapkan berbagai konsep dasar manajemen pelayanan pasien, yang meliputi peran dan fungsi, kompetensi, kegiatan, serta teknis pelaksanaan kegiatan. Berbagai upaya tersebut perlu didasari dengan pemahaman definisi manajemen pelayanan pasien yang baik, yaitu suatu proses kolaboratif dalam melakukan penilaian, perencanaan, fasilitasi, koordinasi pelayanan, evaluasi dan advokasi untuk opsi dan pelayanan bagi pemenuhan kebutuhan komprehensif pasien dan keluarganya, melalui komunikasi dan sumber daya yang tersedia sehingga memberi hasil asuhan pasien yang bermutu dengan biaya efektif 6 .

Peran seorang MPP adalah untuk memfasilitasi pemenuhan kebutuhan asuhan pasien, mengoptimalkan terlaksananya pelayanan berfokus pada pasien dan mengoptimalkan proses reimbursement. Sedangkan fungsinya adalah untuk perencanaan, komunikasi dan koordinasi, edukasi dan advokasi, serta kendali mutu dan biaya pelayanan pasien 5 . Dalam menjalankan peran dan fungsi ini, MPP dituntut untuk memiliki kompentensi yang terdiri dari: konsep manajemen pelayanan pasien, prinsip praktik manajemen pelayanan pasien, manajemen pelayanan kesehatan dan pelaksanaannya, reimbursement pelayanan kesehatan, aspek psikososial asuhan pasien, rehabilitasi, dan pengembangan profesional7. Memastikan dan meningkatkan kompetensi merupakan kunci utama dalam keberhasilan case management. Pimpinan RS perlu membuat pengarahan, perencanaan, panduan, dan pengorganisasian serta monitoring dan evaluasi dalam pengelolaan kompetensi ${ }^{8}$.

Terdapat 10 tahapan yang dilakukan oleh MPP saat melakukan kegiatan pada pasien secara individual, yaitu: identifikasi, seleksi/skrining pasien untuk manajemen pelayanan pasien, asesmen untuk manajemen pelayanan pasien, identifikasi masalah dan kesempatan, identifikasi harapan/sasaran pasien, perencanaan manajemen pelayanan pasien, monitoring, fasilitasi, koordinasi, komunikasi dan kolaborasi, advokasi, hasil pelayanan, dan terminasi manajemen pelayanan pasien ${ }^{6}$. Dalam keseluruhan tahap ini, kegiatan terkait koordinasi pelayanan menjadi kegiatan yang paling banyak membutuhkan waktu MPP, sehingga kemampuan untuk berkomunikasi dan bernegosiasi dengan para profesional lain, serta pasien dan keluarga menjadi sangat penting 9 .

Secara teknis pelaksanaan kegiatan harian MPP terdiri dari: mengidentifikasi pasien untuk intervensi manajemen pelayanan pasien, melakukan kolaborasi dengan profesional pemberi asuhan, dan pasien untuk mengidentifikasi hasil yang diharapkan dan mengembangkan suatu rencana manajemen pelayanan pasien, memonitor intervensi yang relevansi dengan rencana manajemen pelayanan pasien, memonitor kemajuan pasien kearah hasil yang diharapkan juga dalam konteks manajemen pelayanan pasien, menyarankan alternatif intervensi praktis yang efisien biaya, mengamankan sumbersumber klinis untuk mencapai hasil yang diharapkan, dan membakukan jalur-jalur komunikasi dengan para manajer departemen/bagian/unit ${ }^{6}$. Aspek teknis ini memberikan gambaran bahwa bagi pasien dan keluarganya, MPP ibarat pemandu selama perjalanan mereka memperoleh pelayanan di RS.

Pandemi Covid-19 memberikan banyak perubahan yang memang tidak dapat dihindari. Memahami konsep dasar manajemen pelayanan pasien tersebut menjadi dasar untuk menjadi MPP yang efektif, yaitu mereka yang memiliki pola pikir adaptif, menyadari pentingnya melakukan perubahan agar dapat mempertahankan kinerja, mutu dan keselamatan pasien. Mereka juga menunjukkan rasa tanggung jawab yang besar 
dalam mengelola berbagai pengetahuan sebagai mekanisme pembelajaran, dan melakukan berbagai upaya pengembangan profesional, termasuk mendapatkan berbagai keterampilan baru yang dibutuhkan ${ }^{10}$. Dukungan penuh perlu diberikan oleh para pengelola RS untuk revitalisasi MPP, dalam upaya memastikan bahwa seluruh pasien dapat mengakses pelayanan yang diperlukan secara berkelanjutan. Suatu harapan yang didambakan oleh banyak pihak pada saat ini.

\section{Referensi}

1. Gemelli Against COVID-19 Post-Acute Care Study Group. PostCOVID-19 global health strategies: the need for an interdisciplinary approach. Aging Clin Exp Res. 2020;32(8):161320.

2. Tahan HM. Essential case management practices amidst the novel Coronavirus disease 2019 (COVID-19) crisis: Part 1: Tele-case management, surge capacity, discharge planning, and transitions of care: Tele-case management, surge capacity, discharge planning, and transitions of care. Prof Case Manag. 2020;25(5):248-66.

3. Kementerian Kesehatan RI dan Komisi Akreditasi Rumah Sakit. Standar akreditasi rumah sakit. Kerjasama Direktorat Jenderal Bina Upaya Kesehatan Kementerian Kesehatan RI Dengan Komisi Akreditasi Rumah Sakit. 2011.
4. Komisi Akreditasi Rumah Sakit. Standar nasional akreditasi rumah sakit (SNARS) edisi 1.1. Komisi Akreditasi Rumah Sakit. 2019.

5. Joo JY, Liu MF. Experiences of case management with chronic illnesses: a qualitative systematic review. Int Nurs Rev. 2018;65(1):102-13

6. Komisi Akreditasi Rumah Sakit. Panduan praktik manajer pelayanan pasien. Komisi Akreditasi Rumah Sakit. 2016.

7. Tahan HM, Watson AC, Sminkey PV. Informing the content and composition of the CCM certification examination: A national study from the commission for case manager certification: Part 2. Prof Case Manag. 2016;21(1):3-21; quiz E1-2.

8. Avia I, Handiyani H, Nurdiana. (2019). Analisis kompetensi case manager pada rumah sakit di Jakarta: studi kasus. Jurnal Perawat Indonesia. 2019;3(1), 16-27.

9. You EC, Dunt D, Doyle C. How do case managers spend time on their functions and activities? BMC Health Serv Res. 2016;16(1):112.

10. Tahan HM. To exist as a case manager is to constantly change; To be successful, you must constantly adapt. Prof Case Manag. 2018;23(3):103-6. 